\title{
OVERQUALIFICATION: PERMANENT OR TRANSITORY?
}

\author{
DAVID DORN* and ALFONSO SOUSA-POZA \\ UNIVERSITY OF ST. GALLEN
}

Abstract: This paper analyzes job mismatches in Switzerland based on a subjective measure of overqualification. According to job search and job matching theories, overqualification is a transitory problem for the individual worker that results from informational deficits. This problem ceases to exist once access to better information about the labor market allows the worker to move to a job with a better match. Other theories, however, show that overqualification can also be of a permanent nature because of lasting rigidities such as geographical immobility or discriminatory behavior of employers. Moreover, enduring overqualification may be induced by signaling or sheepskin effects. We test perpetuity of overqualification using panel data from the first five waves of the Swiss Household Panel covering the years 1999 to 2003. Overall, 13\% of all workers assessed themselves as overqualified, $80 \%$ as adequately qualified and $2 \%$ as underqualified. The remaining 5\% stated that there is no relation between their qualifications and their jobs. Our empirical analysis reveals little evidence for lasting rigidities that would cause permanent job mismatches. Rather, spells of overqualification are relatively short: about half of all individuals who were overqualified in a given year had an adequate job match one year later. While a short duration of overqualification would be consistent with job search and job matching theories, our observation that the probability of a job mismatch does not significantly decrease with age is at odds with these theories. Our paper provides an alternative explanation for this phenomenon; specifically, that the constant accumulation of experience and qualifications throughout a worker's career implies that, for a good job match to be maintained, qualification-specific job requirements must increase as the worker ages. Should this not occur, even older workers face a risk of becoming overqualified.

JEL Classification: I21, J24, J62

Keywords: overqualification, overeducation, job mismatch

\footnotetext{
* Corresponding author: David Dorn, Research Institute for Labor Economics and Labor Law, University of St.Gallen, Guisanstrasse 92, 9010 St. Gallen, Switzerland; E-mail: david.dorn@ unisg.ch. A previous version of this paper has been presented at the International Conference on Educational Economics in Tartu, Estonia, August 2005. We thank the participants of this conference for helpful comments.

Disclaimer: This study has been realized using the data collected in the "Living in Switzerland Survey" (1999-2020) by the Swiss Household Panel (SHP), Université de Neuchâtel, a project financed by the Swiss National Science Foundation Program (Grants 5004-53205 / 5004-57894 / 5004-67304 / 10FI11-103293), www.swisspanel.ch.
} 


\section{Introduction}

The core function of labor markets is to match heterogeneous workers with heterogeneous jobs in such a way that workers' skills coincide with the requirements of their jobs. However, it is welldocumented in the theoretical and empirical economic literature that individual job/qualification mismatches occur. In empirical studies, particular attention has been given to overeducation, the status of individuals who possess more formal education than their jobs require.

Various explanations have been offered for the existence of job/qualification mismatches. One line of literature argues that qualification mismatches are caused by labor market frictions. For example, according to the job shopping and job matching theories developed by Johnson (1978) and Jovanovic (1979), workers and firms cannot perfectly foresee the quality of a job match because of imperfect information. Therefore, workers may accept jobs that turn out not to match their skills. Consequently, these workers seek new positions until they find an appropriate job match. Hence, these theories imply that job mismatches will be short lived and will occur predominantly at the beginning of individual careers.

Another type of rigidity that may lead to overqualification is geographical immobility. According to Frank's (1978) theory of differential overqualification, married women may move to their husbands' job location, thereby impairing their own career opportunities and foregoing potentially better job matches. As a result, they face a situation of enduring overqualification. A different theoretical approach to qualification mismatch assumes that individuals systematically acquire more skills than they can productively use in their jobs. For example, Spence (1973), in his theory of job signaling, argues that at least some skills acquired by workers are not actually needed to fulfill job tasks but rather have the sole purpose of signaling the level of the workers' productivity to potential employers. Consequently, workers face a situation of long-term overqualification because they cannot use all their skills on the job.

A considerable number of empirical studies analyze mismatches between worker education and educational requirements for jobs. In many of these papers (e.g., Alba-Ramírez 1993, Battu et al. 1999), overeducation is understood as a form of job/qualification mismatch, and sometimes the terms 'overeducation' and 'overqualification' are used interchangeably. The main focus of this literature is the effect of overeducation on the returns for schooling (e.g., Duncan and Hoffman 1981, Rumberger 1987, Verdugo and Verdugo 1989, Groot 1996, Sloane et. al. 1999, Bauer 2002). One common finding of these studies is that overeducated workers face a wage penalty compared to 
equally educated individuals because they cannot productively use all of their educational qualifications.

Nevertheless, despite the ambiguous predictions of the theory, relatively little work has been done to determine the permanency of individual spells of overqualification. Such a void is surprising because the duration of overqualification is certainly as important as wage effects in determining how large a problem overqualification is for an affected individual. Previous research based on overeducation measures suggests that job/qualification mismatches are quite stable. For instance, based on a small sample from the Panel Study of Income Dynamics, Robst (1995) finds that about $60 \%$ of the individuals who were overeducated in 1976 were still overeducated nine years later. Similarly, Rubb (2003a) uses the 1992 to 1999 Current Population Surveys to show that about 75\% of the individuals who were overeducated in a given year remained overeducated the following year. Certain evidence for more movement between overeducation and adequate education is provided by Battu et al. (1999) who analyze a sample of 1985 graduates from the University of Birmingham (UK). Of those graduates who had a job that required a degree in 1991, 10.7\% of males and $18.8 \%$ of females were no longer in a degree-job in 1996.

Whereas these results tend to support the notion that overeducation is relatively permanent, it is less certain whether they allow for the conclusion that individual job/qualification mismatches are long lasting. In Rubb's (2003a) study, for instance, individuals are considered overeducated for a particular occupation if their level of schooling exceeds the occupation's national average level of schooling by more than one standard deviation. This common 'standard deviation' definition of overeducation implies that an overeducated worker can only escape overeducation by either changing occupation or leaving employment altogether. ${ }^{1}$ With regard to job match, however, it is perfectly conceivable that an individual match can improve (or worsen) the situation by moving to another job within the same group of occupations or by an adjustment of the requirements for the present job. Therefore, the duration of individual job mismatches can presumably be more realistically analyzed based on a broader measure of overqualification.

This paper uses the first five waves of the Swiss Household Panel (1999-2003) to analyze the permanency of individual job/qualification mismatches based on a measure of subjective overqualification. Section 2 provides a discussion of the differences in the concepts of overeducation and subjective overqualification. Section 3 outlines the characteristics of the Swiss

\footnotetext{
1 Rubb (2003) also reports that some individuals have escaped overeducation by becoming less educated. However, as individuals cannot realistically decrease their number of years of schooling, this is purely a problem of data quality and not a sensible path for escaping overeducation.
} 
Household Panel data. Sections 4 and 5 give the results of the econometric analysis, and section 6 concludes the paper.

\section{Overqualification and overeducation}

In the framework of human capital theory, individual earnings depend on a set of personal characteristics that determine productivity. In the absence of discrimination, these characteristics can be labeled 'individual qualifications'. In a typical earnings equation, the qualification level of an individual is represented by such components as years of schooling, experience, and tenure. These elements can be understood as proxies for a multitude of specific skills such as teamwork skills, leadership skills, and so forth. ${ }^{2}$

Of course, a skill will only have a productivity- and wage-enhancing effect if it can indeed be used by individuals on the job. In the case of skill underutilization, workers will earn salaries below their earnings potential. Consequently, they will try to find jobs in which, optimally, they can make use of all their skills. We will henceforth refer to workers who can make adequate use of their skills on the job as adequately qualified, while skill underutilization will be labeled overqualification.

Objective identification of an individual job/skill mismatch is a considerable empirical challenge because it requires a measurement of the differential between the skills of an individual and the skill requirements of a job. Individual skills can usually be at least approximately measured by such components as schooling, experience, and tenure. However, the definition of job requirements is problematic because it is very difficult to determine the experience and tenure requirements of a job or the extent to which different types of skills can be substituted for each other. One solution is to focus on educational matches only, which makes it relatively easy to determine the educational levels of individuals and the educational requirements of jobs. Previous literature uses several objective methods to identify such a match, ${ }^{3}$ the most common of which is the previously mentioned approach of comparing an individual's educational level to the average or median educational level of persons in the same occupation. Individuals whose level of schooling exceeds the average or median by more than one standard deviation are considered overeducated. Since

\footnotetext{
2 Henceforth, we will use the words 'qualifications' and 'skills' interchangeably.

3 Overviews and discussions of these methods are provided in Groot and Maassen van den Brink (2000), Chevalier (2003), and Rubb (2003b).
} 
education is a key component of an individual's overall qualification, educational mismatch is frequently a viable proxy for an overall qualification mismatch.

Nevertheless, as education is only one of several individual skill components, it is not entirely clear whether a person identified as overeducated would indeed have a bad job/qualification match if the entirety of the qualifications were taken into account. Even though overeducation can be an indicator for overqualification, it does not necessarily imply overqualification. In fact, various contributions to the overeducation literature have cast some doubt on whether overeducation can readily be interpreted as a job mismatch. One line of literature argues that due to imperfections in the measurement of educational skills, some individuals might be wrongly identified as overeducated. Such a problem can arise, for example, when a sample of college graduates contains overachievers and underachievers (Chevalier 2003) or when the individuals have graduated from colleges of different quality (Robst 1995).

A further concern is that individuals with a high level of education who accept jobs with fewer educational requirements might do so because they lack other skills. In particular, overeducation might to some extent compensate for low experience, and the respective individuals might not be overqualified once all qualification elements are taken into account. Sicherman and Galor (1990), Sicherman (1991), and Alba-Ramírez (1993) find that recent college graduates do indeed seem to compensate for their inexperience through higher educational attainment. Moreover, Bauer (2002), using German panel data, shows that after unobservable skills are controlled for by means of a random effects panel regression, the earnings penalty for overeducated workers becomes small and partially no longer significantly different from zero. This finding supports the notion that many workers identified as overeducated have an adequate job/qualification match when the entirety of their skills is evaluated to determine the match's quality.

Additional problems arise if an attempt is made to use an objective measure of overeducation to analyze the permanency of job/qualification mismatches because then, by definition, the educational requirements of a job never change. In fact, all the jobs that belong to the same group of occupations are assumed to have the same requirements. Since the educational attainment of an individual is also relatively stable over time, overeducation will necessarily be found to be relatively stable over time unless there is a high level of interoccupational job mobility. Therefore, we analyze the duration of mismatches based on a measure of subjective overqualification, which has the advantage of not a priori restricting changes of the matching status to interoccupational job changes. Moreover, looking at subjective overqualification rather than subjective overeducation (as, e.g., in Alba-Ramírez 1993) takes into account that an individual's overall qualification will 
probably change over the course of a career, while educational attainment may typically stay constant.

Clearly, however, such conceptions of subjective mismatch also have drawbacks. For example, in his discussion of various definitions of overeducation, Chevalier (2003) argues that subjective measures can be affected by classification error because the researcher cannot know exactly how workers made assessments of their own matching status. At the same time, Chevalier (2003) concedes that only such a self-assessment can take the specific individual matching situation fully into account. This latter feature is crucial for preventing bias in the analysis of individual mismatch permanency owing to usage of a mismatch measure that by definition severely restricts the possibilities for changing the matching status.

\section{Data}

For this study, we use data from the Swiss Household Panel (SHP), a nationwide representative panel survey for Switzerland. Starting in 1999, the SHP data has been collected annually using computer-assisted telephone interviewing. In each of the selected households, a reference person answers a comprehensive personal questionnaire, while the remaining household members only respond to a basic set of questions. The first wave comprised a representative sample of 5,074 households with a total of 12,931 individuals, while the last wave included 3,289 households and 8,478 individuals. In each wave, the employed household reference persons were asked, "How do you estimate your qualifications with regard to your current job?" The four possible answers were as follows: "your qualifications are not sufficient", "your qualifications correspond to your job", "your qualifications are superior to your job", and "your qualifications do not relate to your job". We will subsequently refer to these categories as 'underqualified', 'adequately qualified', 'overqualified', and 'no match'. The latter category reflects the fact that some workers with a very poor job/skill-match might be both overqualified in the sense that they can not use their skills on the job and underqualified in not having the skills required for the job.

The base sample of this study comprises 17,772 pooled observations of individual job matching statuses for individuals aged 25 to 60 . The two genders are nearly equally represented, with 8,916 women and 8,856 men. We also use a sample of 13,673 observations that each refers to an individual's matching status in a year $t$ and a new matching status in the following year $\mathrm{t}+1$. 


\section{Permanency of overqualification}

In a pooled sample of the SHP waves 1999 to $2003,79.5 \%$ of the workers assessed themselves as adequately qualified (table 1 ). The overqualified workers made up $13.4 \%$ of all workers, while $1.9 \%$ reported being underqualified, and the remaining $5.2 \%$ stated that there was no relation between their qualifications and their jobs. We will henceforth focus our analysis on the most important mismatch group - the overqualified workers. As shown in table 1, the incidence of overqualification is similar for both men and women and decreases slightly with age.

Table 1: Incidence of Qualification Match Statuses

\begin{tabular}{lccccc}
\hline & $\begin{array}{c}\text { Adequately } \\
\text { qualified }\end{array}$ & Overqualified & Underqualified & No match & $\begin{array}{c}\text { No. of } \\
\text { observations }\end{array}$ \\
\hline All & $79.5 \%$ & $13.4 \%$ & $1.9 \%$ & $5.2 \%$ & 17.772 \\
Male & $81.4 \%$ & $13.3 \%$ & $2.0 \%$ & $3.3 \%$ & 8.856 \\
Female & $77.7 \%$ & $13.5 \%$ & $1.8 \%$ & $7.0 \%$ & 8.916 \\
Age 25-34 & $76.0 \%$ & $15.7 \%$ & $2.1 \%$ & $6.1 \%$ & 5.379 \\
Age 35-49 & $79.6 \%$ & $13.6 \%$ & $1.9 \%$ & $4.9 \%$ & 8.040 \\
Age 50-60 & $82.5 \%$ & $11.0 \%$ & $1.6 \%$ & $4.9 \%$ & 4.961 \\
\hline
\end{tabular}

Data: Swiss Household Panel 1999-2003 (pooled).

In addition, the self-reported overqualification in Switzerland is lower than the rates of subjective overeducation in almost all of the more than 20 international studies summarized by Groot and Maassen van den Brink (2000). On average, the incidence of self-reported overeducation in these studies was more than $25 \%$. These observations would be consistent with the explanation that educational mismatches are more common than overall job/skill-mismatches; however, because we are not aware of any Swiss dataset that measures overeducation, we cannot make a direct comparison of overqualification and overeducation within Switzerland. Therefore, it is also conceivable that the relatively low incidence of mismatches is a particular feature of the Swiss labor market.

Table 2 details the permanency of individual overqualification. We find that overqualification is short lived for individuals. More than $60 \%$ of the workers who become overqualified in a given year escape overqualification the following year; about $80 \%$ have escaped overqualification after two years, and close to $90 \%$ after three years. Of those workers who were overqualified in 1999 , only one in 13 persons remained constantly overqualified throughout the timeframe of 1999 to 2003. Hence, the long-term component of overqualification is quite small, and the labor market seems to perform well in dissolving overqualification. 
This result supports our hypothesis that an analysis based on overeducation might give a misleading impression about the permanency of individual job mismatches. The findings by Rubb (2003a) that only $26 \%$ of the individuals overeducated in a given year had escaped overeducation one year later - are hardly the consequence of a low flexibility of the U.S. labor market. Rather, the overeducation measure itself implies a relatively large stability.

Table 2: Permanency of Overqualification

\begin{tabular}{|c|c|c|c|c|c|}
\hline \multirow{2}{*}{$\begin{array}{c}\text { Overqualification } \\
\text { begins }\end{array}$} & \multicolumn{4}{|c|}{ Overqualification remains } & \multirow{2}{*}{$\begin{array}{c}\text { No. of } \\
\text { observations }\end{array}$} \\
\hline & One year later & Two years later & $\begin{array}{c}\text { Three years } \\
\text { later }\end{array}$ & Four years later & \\
\hline 1999 (or earlier) & $44.4 \%$ & $19.6 \%$ & $11.1 \%$ & $7.7 \%$ & 271 \\
\hline 2000 & $36.9 \%$ & $22.0 \%$ & $12.1 \%$ & & 141 \\
\hline 2001 & $37.0 \%$ & $20.5 \%$ & & & 146 \\
\hline 2002 & $38.5 \%$ & & & & 148 \\
\hline
\end{tabular}

Data: Swiss Household Panel 1999-2003.

Table 3 compares the individual changes in matching status for overqualified or adequately qualified individuals in a given year. Again, there seems to be a relatively quick dissolution of overqualification because more than $46 \%$ of the individuals who were overqualified in year $t$ reported an adequate job match in year $\mathrm{t}+1$. The portion remaining overqualified for at least another year is only $42 \%$. At the same time, the probability that an adequately qualified individual becomes overqualified is a modest $7.7 \%$.

Table 3: Individual Changes in Matching Status

\begin{tabular}{|c|c|c|c|c|c|c|}
\hline \multirow{2}{*}{ Status in $\mathrm{t}+1$} & \multicolumn{3}{|c|}{ Overqualified in $\mathrm{t}$} & \multicolumn{3}{|c|}{ Adequately qualified in $\mathrm{t}$} \\
\hline & All & Males & Females & All & Males & Females \\
\hline Adequately qualified & $46.4 \%$ & $49.2 \%$ & $43.6 \%$ & $83.3 \%$ & $86.8 \%$ & $80.7 \%$ \\
\hline Overqualified & $41.9 \%$ & $42.3 \%$ & $41.5 \%$ & $7.7 \%$ & $7.8 \%$ & $7.5 \%$ \\
\hline Other mismatch & $5.7 \%$ & $4.6 \%$ & $6.7 \%$ & $4.3 \%$ & $3.7 \%$ & $5.0 \%$ \\
\hline Unemployed & $2.1 \%$ & $2.3 \%$ & $1.9 \%$ & $0.8 \%$ & $0.7 \%$ & $1.0 \%$ \\
\hline Not working & $3.9 \%$ & $1.7 \%$ & $6.2 \%$ & $3.4 \%$ & $1.1 \%$ & $5.8 \%$ \\
\hline No. observations & 1.674 & 840 & 834 & 9.916 & 5.041 & 4.875 \\
\hline
\end{tabular}

Data: Swiss Household Panel 1999-2003 (pooled).

A further observation from table 3 is that overqualified workers seem to face a higher risk of becoming unemployed. This finding is consistent with similar results in overeducation studies (e.g., Sloane et al. 1999). The most important gender difference related to changes in matching status is 
that women are much more likely than men to leave the labor market. However, this observation does not hold only for overqualified women but also for those who are adequately qualified.

Of course, the chances of becoming overqualified differ depending on certain individual characteristics. Table 4 shows multinominal logit estimates for the transitions from adequate qualification to overqualification and vice versa. ${ }^{4}$ The results show no significant impact of gender or marital status on the probability of becoming overqualified. This finding is evidence against Frank's (1978) theory of differential overqualification, which suggests that overqualification is particularly widespread among married women because their job search is spatially constrained to the region in which the husband (as primary earner) has found a suitable job. Specific empirical tests of the differential overqualification hypothesis based on overeducation measures also fail to provide strong support for this theory (McGoldrick and Robst 1996, Büchel and Battu 2003).

Individuals with a high educational level run a particularly high risk of becoming overqualified. Clearly, overqualification is particularly relevant for those individuals having high qualifications. Moreover, consistent with job search theory, the chance of becoming overqualified decreases with tenure as mismatches become apparent to both employee and employer during the first few years of employment and are quickly dissolved so that only individuals with a good job/qualification match reach higher tenure. Conversely, however, the probability of becoming overqualified does not decrease with experience. This observation provides evidence against the notion that overqualification primarily affects young individuals and is consistent with the finding (given in table 1) that the incidence of overqualification only modestly decreases with age.

The second part of table 4 shows the impact of some individual characteristics on the probability of an overqualified person moving to an adequate job match (relative to the probability of remaining overqualified). For women and married individuals, the odds of escaping overqualification seem to be somewhat smaller than for men and singles; however, these effects are not statistically significant at any conventional level. Individuals with a low educational level have a good chance of escaping overqualification, while neither experience nor tenure displays any sizable or significant effects.

\footnotetext{
${ }^{4}$ The regressions are estimated using the five outcome categories of 'adequately qualified', 'overqualified', 'underqualified', 'no match', and 'not employed/unemployed'. However, only the most relevant results - namely, the transitions from adequate qualification to overqualification and from overqualification to adequate qualification - are shown here.
} 
Table 4: Transitions Between Adequate Qualification and Overqualification - Multinominal Logit Regressions

\begin{tabular}{|c|c|c|c|c|c|c|}
\hline \multicolumn{7}{|c|}{ Adequately qualified individuals in $t$ : Determinants of becoming overqualified in $t+1$} \\
\hline & \multicolumn{2}{|c|}{ All } & \multicolumn{2}{|c|}{ Males } & \multicolumn{2}{|c|}{ Females } \\
\hline & Coeff. & S.E. & Coeff. & S.E. & Coeff. & S.E. \\
\hline Female & -0.033 & 0.097 & & & & \\
\hline Married & -0.077 & 0.095 & -0.206 & 0.131 & 0.078 & 0.134 \\
\hline Low education & -0.167 & 0.182 & 0.105 & 0.279 & $-0.425^{*}$ & 0.223 \\
\hline High education & $0.189 * *$ & 0.093 & $0.254 * *$ & 0.125 & 0.117 & 0.139 \\
\hline Experience & -0.001 & 0.001 & 0.003 & 0.008 & -0.003 & 0.008 \\
\hline Tenure & $-0.021 * * *$ & 0.008 & $-0.024 * * *$ & 0.009 & -0.014 & 0.013 \\
\hline Other variables incl. & & & & & & \\
\hline Other categories & & & & & & \\
\hline No. observations & & & & & & \\
\hline Log pseudo-likelihood & & & & & & \\
\hline \multicolumn{7}{|c|}{ Overqualified individuals in $t$ : Determinants of becoming adequately qualified in $t+1$} \\
\hline & \multicolumn{2}{|c|}{ All } & \multicolumn{2}{|c|}{ Males } & \multicolumn{2}{|c|}{ Females } \\
\hline & Coeff. & S.E. & Coeff. & S.E. & Coeff. & S.E. \\
\hline Female & -0.088 & 0.142 & & & & \\
\hline Married & -0.190 & 0.141 & -0.159 & 0.194 & -0.222 & 0.192 \\
\hline Low education & $0.617 *$ & 0.321 & $2.699 * *$ & 1.050 & 0.128 & 0.349 \\
\hline High education & -0.179 & 0.141 & -0.181 & 0.190 & -0.149 & 0.207 \\
\hline Experience & 0.002 & 0.009 & 0.001 & 0.011 & -0.001 & 0.015 \\
\hline Tenure & 0.008 & 0.011 & 0.013 & 0.014 & -0.003 & 0.020 \\
\hline Other variables incl. & \multicolumn{2}{|c|}{3} & \multicolumn{2}{|c|}{3} & \multicolumn{2}{|c|}{3} \\
\hline Other categories & \multicolumn{2}{|c|}{4} & \multicolumn{2}{|c|}{4} & \multicolumn{2}{|c|}{4} \\
\hline No. observations & \multicolumn{2}{|c|}{1.520} & \multicolumn{2}{|c|}{795} & \multicolumn{2}{|c|}{725} \\
\hline Log pseudo-likelihood & \multicolumn{2}{|c|}{-1570.8} & \multicolumn{2}{|c|}{-777.1} & \multicolumn{2}{|c|}{-783.2} \\
\hline
\end{tabular}

Note: All models include the five outcome categories 'adequately qualified', 'overqualified', 'underqualified', 'no match', and 'not employed/unemployed'. For the first three models, only the results for the 'overqualification' category are shown, while 'adequate qualification' is the reference category. For the second three models, only the results for the 'adequate qualification' category are shown, while 'overqualification' is the reference category. Results for the other categories are available from the authors upon request. Observations are weighted to accurately represent the Swiss population. Standard errors are clustered by respondents. All models include a constant and variables for the paired years $2000 / 2001,2001 / 2002,2002 / 2003$. $* * * / * * *$ denotes significance at the $10 \% / 5 \% / 1 \%$ level.

Data: Swiss Household Panel 1999-2003 (pooled). 


\section{Changes of Occupation and Employer}

Because individuals are expected to seek an adequate job/qualification match, it can be predicted that workers facing a mismatch are more likely to change occupations or employers than their already well-matched peers. The results presented in table 5 show that relative to the reference category of adequately qualified workers, individuals with any type of qualification mismatch do indeed have an increased probability of changing occupation or employer. In the case of overqualification, these effects are consistently highly significant for both genders, which corresponds to similar results obtained using overeducation measures (e.g., Sicherman 1991, AlbaRamírez 1993).

Table 5: Determinants of Occupation and Employer Change - Probit Regressions

Determinants of occupation change between years $t$ and $t+1$

All

Coeff.

$0.230 * * *$

$0.271 *$

$0.402 * * *$

(0.084)

17

Other variables incl.

No. observations

13.673

Log pseudo-likelihood
Males

S.E.

Coeff.

$0.239 * * *$

0.237

$0.497 * * *$

16

7.085

$-1112.0$
Females

S.E.

(0.076)

(0.185)

(0.128)

$0.335 * * *$

$0.239 * * *$

S.E.

6

16

6.588

$-993.1$

Determinants of employer change between years $t$ and $t+1$

All

Males

Females

\begin{tabular}{|c|c|c|c|c|c|c|}
\hline & Coeff. & S.E. & Coeff. & S.E. & Coeff. & S.E. \\
\hline Overqualified in $\mathrm{t}$ & $0.231 * * *$ & $(0.048)$ & $0.211 * * *$ & $(0.068)$ & $0.269 * * *$ & $(0.068)$ \\
\hline Underqualified in $\mathrm{t}$ & $0.243^{* *}$ & $(0.113)$ & $0.307 * *$ & $(0.148)$ & 0.136 & $(0.182)$ \\
\hline No match in $\mathrm{t}$ & 0.117 & $(0.078)$ & $0.228 *$ & $(0.121)$ & 0.038 & $(0.101)$ \\
\hline Other variables incl. & \multicolumn{2}{|c|}{17} & \multicolumn{2}{|c|}{16} & \multicolumn{2}{|c|}{16} \\
\hline No. observations & \multicolumn{2}{|c|}{13.673} & \multicolumn{2}{|c|}{7.085} & \multicolumn{2}{|c|}{6.588} \\
\hline Log pseudo-likelihood & \multicolumn{2}{|c|}{-3658.0} & \multicolumn{2}{|c|}{-1861.0} & \multicolumn{2}{|c|}{-1772.5} \\
\hline
\end{tabular}

Note: The reference group for qualification status is 'adequately qualified'. Observations are weighted to accurately represent the Swiss population. Standard errors are clustered by respondents. All models include a constant and the additional variables female (in the full sample regression only), married, eight variables for educational levels, experience, experience squared, tenure, tenure squared, and variables for the paired years 2000/2001, 2001/2002, $2002 / 2003 . * / * * * * *$ denotes significance at the $10 \% / 5 \% / 1 \%$ level.

Data: Swiss Household Panel 1999-2003 (pooled).

In previous research that analyzes job mismatches based on overeducation, there is by definition a very close link between changes in occupation and changes in matching status. Most particularly, 
when, as in Rubb (2003a), an objective overeducation measure is used, an individual change in mismatch status requires either a job change or a change in educational attainment. Since worker educational level barely changes during a career, a job change is almost a necessary condition for a change in matching status. Therefore, by using a measure of subjective overqualification to determine job mismatches, we avoid imposing any restrictive conditions on changes in the matching status - individuals can change their matching status without moving to a new occupation.

Table 6: Occupation/Employer Change and Changes in Qualification Match Status

\begin{tabular}{|c|c|c|c|c|c|c|}
\hline \multicolumn{7}{|c|}{ Percentage of specified group that changed occupation between $t$ and $t+1$} \\
\hline & \multicolumn{2}{|c|}{ All } & \multicolumn{2}{|c|}{ Males } & \multicolumn{2}{|c|}{ Females } \\
\hline $\begin{array}{l}\text { Overqualified in both } \\
\text { periods }\end{array}$ & $3.3 \%$ & $(\mathrm{~N}=767)$ & $2.8 \%$ & $(\mathrm{~N}=391)$ & $3.7 \%$ & $(\mathrm{~N}=376)$ \\
\hline $\begin{array}{l}\text { Overqualified in } \mathrm{t} \text {, } \\
\text { adequately qu. in } \mathrm{t}+1\end{array}$ & $7.5 \%$ & $(\mathrm{~N}=884)$ & $8.3 \%$ & $(\mathrm{~N}=471)$ & $6.5 \%$ & $(\mathrm{~N}=413)$ \\
\hline $\begin{array}{l}\text { Adequately qu. in } \mathrm{t} \text {, } \\
\text { overqualified in } \mathrm{t}+1\end{array}$ & $4.4 \%$ & $(\mathrm{~N}=856)$ & $4.9 \%$ & $(\mathrm{~N}=449)$ & $3.9 \%$ & $(\mathrm{~N}=407)$ \\
\hline $\begin{array}{l}\text { Adequately qualified in } \\
\text { both periods }\end{array}$ & $2.8 \%$ & $(\mathrm{~N}=9.521)$ & $2.9 \%$ & $(\mathrm{~N}=5.034)$ & $2.8 \%$ & $(\mathrm{~N}=4.487)$ \\
\hline \multicolumn{7}{|c|}{ Percentage of specified group that changed employer between $t$ and $t+1$} \\
\hline & \multicolumn{2}{|c|}{ All } & \multicolumn{2}{|c|}{ Males } & \multicolumn{2}{|c|}{ Females } \\
\hline $\begin{array}{l}\text { Overqualified in both } \\
\text { periods }\end{array}$ & $7.2 \%$ & $(\mathrm{~N}=767)$ & $7.7 \%$ & $(\mathrm{~N}=391)$ & $6.6 \%$ & $(\mathrm{~N}=376)$ \\
\hline $\begin{array}{l}\text { Overqualified in } \mathrm{t} \text {, } \\
\text { adequately qu. in } \mathrm{t}+1\end{array}$ & $17.3 \%$ & $(\mathrm{~N}=884)$ & $15.3 \%$ & $(\mathrm{~N}=471)$ & $19.6 \%$ & $(\mathrm{~N}=413)$ \\
\hline $\begin{array}{l}\text { Adequately qu. in } \mathrm{t} \text {, } \\
\text { overqualified in } \mathrm{t}+1\end{array}$ & $11.0 \%$ & $(\mathrm{~N}=856)$ & $10.5 \%$ & $(\mathrm{~N}=449)$ & $11.5 \%$ & $(\mathrm{~N}=407)$ \\
\hline $\begin{array}{l}\text { Adequately qualified in } \\
\text { both periods }\end{array}$ & $7.0 \%$ & $(\mathrm{~N}=9.521)$ & $6.7 \%$ & $(\mathrm{~N}=5.034)$ & $7.3 \%$ & $(\mathrm{~N}=4.487)$ \\
\hline
\end{tabular}

Note: Brackets indicated the total number of observations in the specified group.

Data: Swiss Household Panel 1999-2003 (pooled).

Table 6 shows the incidence of occupation and employer changes for workers who moved from adequate qualification to overqualification and from overqualification to adequate qualification, as well as for those who stayed adequately qualified or overqualified, respectively. We find that the share of individuals who have changed their occupation or employer is larger for those who changed their matching status than for those who did not. Occupation and employer changes were particularly frequent among those individuals who moved from overqualification to adequate qualification, while few changes took place among the large group of individuals who consistently had an adequate job match. 
At the same time, table 6 illustrates that only $7.5 \%$ of the individuals who moved from overqualification to adequate qualification changed their occupation. The incidence of those who found an adequate match by moving to a new employer (in the same or in a different occupation) is $17.3 \%$. However, more than $80 \%$ of the overqualified individuals who moved to an adequate job/qualification match did so without changing either occupation or employer. Among the adequately qualified individuals who become overqualified, the respective share is even larger.

One explanation for these results rests on the fact that individual qualifications change constantly over time. If we represent qualifications by the three main explanatory variables of a typical wage regression - namely, schooling, experience, and tenure - it is immediately obvious that only the level of schooling is relatively stable over time, while experience and tenure are constantly increasing. In other words, the qualifications of an individual grow continuously., and a wellestablished consequence of this growth is an increasing wage profile during most of the individual's career.

At the same time, to maintain an adequate job/qualification match, job requirements must be increased at least periodically to match the growing qualifications of an employee. If such an adjustment does not occur in a timely manner, the accumulated qualifications of an individual will increasingly surpass the unchanged job requirements. As a result, the individual will become overqualified even though no occupation or employer change has taken place.

Employers have several motivations for preventing their employees from becoming overqualified. As shown in table 5, overqualification increases the probability that employees will move to another employer, and therefore employers risk losing employees who have become overqualified. This outcome is particularly undesirable if the respective employees have acquired valuable company-specific skills and experience and if it is costly to find suitable replacement workers. Moreover, some authors (e.g., Tsang and Levin 1985) argue that an underutilization of skills might, at least in the long run, lead to adverse workplace behavior such as low work effort or increased absenteeism. Such a possibility incentivizes employers to adjust job requirements to evolving individual qualifications. For instance, they may promote employees to jobs higher in the hierarchy or alter job tasks and responsibilities. These measures can effectively prevent or put an end to overqualification without any occupation or employer change on the part of the employee. Clearly, it is also conceivable that, for similar reasons, employees will try to negotiate such an internal solution to an imminent or existing overqualification problem. Finding an adequate job match with their present employer allows them to further utilize their company-specific skills, and the search for a matching job with the current employer may be less costly than a job search with a new 
employer. As a result, many adjustments of individual matching status occur while an employee remains with the present employer.

\section{Conclusion}

This paper analyzes the persistence of individual job mismatches defined by a subjective overqualification measure that is superior to previously used overeducation measures in capturing the dynamic aspects of mismatches.

Using a large Swiss panel dataset, we find that individual overqualification is only a transitory phenomenon: close to $90 \%$ of the affected workers escape overqualification within three years after becoming overqualified. This finding is evidence against the assumption of strong signaling effects, which implies that individuals must acquire far more skills than required by a job in order to be accepted for that job. Moreover, there seem to be no fundamental rigidities preventing certain groups of workers from finding jobs that match their qualifications. In particular, there is no evidence for an increased incidence of lasting overqualification among married women that could result from spatial and family-tie rigidities as proposed by the theory of differential overqualification.

However, overqualification does strongly increase the probability that a worker will move to another employer or even to another occupation because, in most cases, this move allows affected individuals to find an adequate job/qualification match. Nevertheless, changes in individual matching status do not only occur in the rather rare situations of occupation or employer change. On the contrary, many individuals move into, and out of, overqualification while remaining with the same employer and working in the same occupation. This finding is consistent with the notion that workers will become overqualified for their present job if the job requirements are not adjusted to their continuously growing individual qualifications. Moreover, because such failures in this adjustment process can occur at any time in an individual's career, overqualification is not, as suggested by job matching and job shopping theories, restricted to new entrants into the labor market. Rather, the empirical results of this paper imply that overqualification, while short lived for the individual, can affect workers with different levels of experience alike. 


\section{References}

1. Alba-Ramírez, Alfonso (1993), "Mismatch in the Spanish Labor Market: Overeducation?", Journal of Human Resources 28(2): 259-278.

2. Battu, Harminder, Clive R. Belfield, and Peter J. Sloane (1999), "Overeducation Among Graduates: A Cohort View", Education Economics 7(1): 21-38.

3. Bauer, Thomas K. (2002), "Educational Mismatch and Wages: A Panel Analysis", Economics of Education Review 21: 221-229.

4. Büchel, Felix, and Harminder Battu (2003), "The Theory of Differential Overqualification: Does It Work?", Scottish Journal of Political Economy 50(1): 1-16.

5. Chevalier, Arnaud (2003), "Measuring Over-education", Economica 70: 509-531.

6. Duncan, Greg J., and Saul D. Hoffmann (1981), "The Incidence and Wage Effects of Overeducation", Economics of Education Review 1(1): 75-86.

7. Frank, Robert H. (1978), "Why Women Earn Less: The Theory and Estimation of Differential Overqualification", American Economic Review 68(3): 360-373.

8. Groot, Wim (1996), "The Incidence of, and Returns to, Overeducation in the UK", Applied Economics 28: 1345-1350.

9. Groot, Wim, and Henriëtte Maassen van den Brink (2000), "Overeducation in the Labor Market: A Meta-analysis", Economics of Education Review 19: 149-158.

10. Johnson, William R. (1978), "A Theory of Job Shopping", Quarterly Journal of Economics 92(2): 261-278.

11. Jovanovic, Boyan (1979), "Job Matching and the Theory of Turnover", Journal of Political Economy 87(5): 972-990.

12. McGoldrick, KimMarie, and John Robst (1996), "Gender Differences in Overeducation: A Test of the Theory of Differential Overqualification", American Economic Review 86(2), Papers and Proceedings of the 108th Annual Meeting of the American Economic Association San Francisco, CA, January 5-7, 1996 (May 1996): 280-284.

13. Robst, John (1995), "College Quality and Overeducation", Economics of Education Review 14(3): 221-228.

14. Rubb, Stephen (2003a), "Overeducation: A Short or Long Run Phenomenon for Individuals?", Economics of Education Review 22: 389-394.

15. Rubb, Stephen (2003b), "Overeducation in the Labor Market: A Comment and Re-analysis of a Meta-analysis", Economics of Education Review 22: 621-629.

16. Rumberger, Russell W. (1987), "The Impact of Surplus Schooling on Productivity and Earnings", Journal of Human Resources 22(1): 24-50. 
17. Sicherman, Nachum, and Oded Galor (1990), "A Theory of Career Mobility", Journal of Political Economy 98(1): 169-192.

18. Sicherman, Nachum (1991), "Overeducation in the Labor Market", Journal of Labor Economics 9(4): 101-122.

19. Sloane, Peter J., Harminder Battu, and Paul T. Seaman (1999) , "Overeducation, Undereducation and the British Labour Market", Applied Economics 31: 1437-1453.

20. Spence, Michael (1973), "Job Market Signaling", Quarterly Journal of Economics 87(3): $355-374$.

21. Tsang, Mun C., and Henry M. Levin (1985), "The Economics of Overeducation", Economics of Education Review 4(2): 93-104.

22. Verdugo, Richard R., and Naomi Turner Verdugo (1989), "The Impact of Surplus Schooling. Some Additional Findings", Journal of Human Resources 24(4): 629-643. 